\title{
Understanding the Temporal Variability of Rainfall for Estimating Agro-Climatic Onset of Cropping Season over South Interior Karnataka, India
}

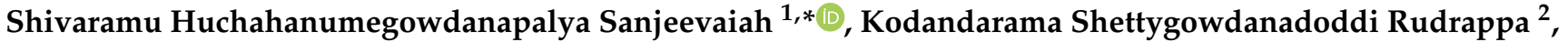 \\ Mohankumar Thavakadahalli Lakshminarasappa ${ }^{2}$, Lingaraj Huggi ${ }^{3}{ }^{(0)}$, Manjunatha Melekote Hanumanthaiah ${ }^{1}$, \\ Sowmya Dadireddihalli Venkatappa ${ }^{1}$, Nagesha Lingegowda ${ }^{1}$ and Sheshshayee M. Sreeman ${ }^{4}$
}

Citation: Sanjeevaiah, S.H.; Rudrappa, K.S.; Lakshminarasappa, M.T.; Huggi, L.; Hanumanthaiah, M.M.; Venkatappa, S.D.; Lingegowda, N.; Sreeman, S.M. Understanding the Temporal Variability of Rainfall for Estimating Agro-Climatic Onset of Cropping Season over South Interior Karnataka, India. Agronomy 2021, 11, 1135. https://doi.org/10.3390/ agronomy11061135

Academic Editor: Ajit Govind

Received: 15 May 2021

Accepted: 28 May 2021

Published: 2 June 2021

Publisher's Note: MDPI stays neutral with regard to jurisdictional claims in published maps and institutional affiliations.

Copyright: (c) 2021 by the authors. Licensee MDPI, Basel, Switzerland. This article is an open access article distributed under the terms and conditions of the Creative Commons Attribution (CC BY) license (https:/ / creativecommons.org/licenses/by/ $4.0 /)$.
1 Agrometeorology Section, University of Agricultural Sciences, GKVK, Bengaluru 560065, India; mh.manjunatha@rediffmail.com (M.M.H.); dvsoumya@gmail.com (S.D.V.); nageshamb@gmail.com (N.L.)

2 Department of Agricultural Statistics, Applied Mathematics and Computer Science, University of Agricultural Sciences, GKVK, Bengaluru 560065, India; kodandarama008@gmail.com (K.S.R.); mohankumartl@UASBangalore.edu.in (M.T.L.)

3 Indo-French Cell for Water Sciences, Indian Institute of Science, Bengaluru 560012, India; lingarajhuggi@gmail.com

4 Department of Crop Physiology, University of Agricultural Sciences, GKVK, Bengaluru 560065, India; msshesh1@uasbangalore.edu.in

* Correspondence: bng.aicrpam@gmail.com

\begin{abstract}
Annual, seasonal and intra-seasonal variations in rainfall affect crop production from land preparation to the realization of potential crop yield in a region. Particularly, the onset of the rainy season is most crucial for determining the sowing period. Statistical analysis (Modified Mann-Kendall aka MMK-test for trend and likelihood ratio test for shifting pattern) of 60 years rainfall of south interior Karnataka (SIK) inferred the presence of temporal variability in rainfall. There was a monotonic increase in rainfall of February, March, April, June and August months (a positive sign of MM-K (tau) value), with a negligible rate of change (Sen's slope towards zero). Upon seasonal analysis, there was a significant increase in winter, pre-monsoon and monsoonal rainfall as compared to post-monsoonal rainfall (higher Sen's slope for pre-monsoon), indicating a need for agronomic interventions for estimating an effective date of sowing for reducing risks of crop production. Further, the agro-climatic onset of cropping season was estimated by considering soil-crop-water relations. Earlier onset of cropping season was estimated based on thresholds of soil-crop-water relations, which highlights sowing of crops in advance (May 1st fortnight) instead of late (June 1st fortnight) to avoid crop losses due to early-season drought.
\end{abstract}

Keywords: rainfall trend; rainfall shift; early season drought; onset; SIK

\section{Introduction}

Among several features of monsoonal regions of the world, seasonal variation of rainfall is the most distinguishing. About $80 \%$ of the annual rainfall in India occurs during the summer monsoon period, June-September [1]. The year-to-year variability in monsoon rainfall occasionally leads to extreme hydrological events (large-scale droughts and floods), resulting in a serious reduction in agricultural output and affecting the vast population (in excess of one billion) and the national economy [2]. A normal monsoon with an evenly distributed rainfall throughout the country is a bonanza, while an extreme event of flood or drought over the entire country or a smaller region constitutes a natural hazard. Hence the variation in seasonal monsoon rainfall may be considered a measure to examine climate variability/change over the Indian monsoon domain in the context of global warming [3].

Rainfall plays a dominant role in agricultural production and productivity, despite advancement in many technological fronts. The fourth assessment report (AR4) of the 
Inter-governmental Panel on Climate Change (IPCC) (2007) [4] indicated with very high confidence (90\% probability of being correct) that human activities, since industrialization, have caused the planet to warm by about $1{ }^{\circ} \mathrm{C}$ and future climate change is likely to affect agriculture and increase the risk of hunger and water scarcity [5]. The intra-annual, interseasonal and intra-seasonal rainfall variations affect agriculture from land preparation to the realization of the potential yield of crops [6], and seasonal changes in rainfall patterns may alter the cropping pattern and cropping system [7].

Many attempts for prediction of monsoon onset have been made for different time scales using numerical prediction models [8]. Forecasting methods have so far been mostly based on statistical model approaches, which include averaged values of zonal asymmetric temperature anomaly [9], sea surface temperature, mean sea level pressure [8,10], tropospheric moisture buildup over areas south of the Indian peninsula [11], vertically integrated moisture budget (hydrologic onset and withdrawal index) [12], moist static energy [13], outgoing longwave radiation (OLR), wind fields [14] and, recently, critical transition precursor-based methods considering precipitation along with air temperature and relative humidity were considered to estimate the onset and withdrawal [15]. However, there are certain difficulties in the existing forecasting methods, in particular, of false monsoon onsets mostly related to non-monsoonal atmospheric circulation systems [16]. These limitations require improvements in the prediction skills for monsoon onset.

The subject area of climate change is vast; the changing pattern of rainfall is a topic within this field that deserves urgent and systematic attention since it affects both the availability of fresh water and food production [17]. Higher the rainfall or lower the rainfall or changes in its spatial and seasonal distribution would influence the spatial and temporal distribution of runoff, soil moisture and groundwater reserves and would affect the frequency of droughts and floods. Unlike irrigated agriculture, rainfed farming is usually diverse and risk-prone. Small variations in the timing and the quantity of rainfall have a potential impact on agricultural output [18]. Among the states, Karnataka is facing frequent drought conditions due to uncertainty in rainfall and spatiotemporal variation in different regions.

Due to these variations in rainfall distribution, Karnataka is experiencing extreme weather conditions such as drought or flood in different regions. Frequent drought and floods have caused heavy loss to crops and lives, while society loses its livelihood and rhythm of life, and people are forced to migrate for their sustenance. As rainfall is an unpredictable natural phenomenon, statistical analysis of its distribution patterns and quantum of rainfall plays an important role [19]. The statistical analysis of rainfall paves the way for help the government in agricultural planning and policymaking and for farmers in adopting the farm production practices, crop contingency planning, etc. [20].

In southern Karnataka, major soil types are sandy clay, some drought-tolerant crops such as pigeonpea, finger millet, sugarcane etc., are grown, but local varieties are not very productive. These low yields and their high variability, combined with the fast demographic increase, are the main cause of recurrent food crises. Many reasons explain the weakness and spatiotemporal variability of crop yields in these regions. One of the most important risk factors is the high spatial and temporal variability of rainfall across the region [21]; this is exacerbated by poor soil fertility [22]. The rainy season lasts from April to November and receives between 528 to $1374 \mathrm{~mm}$ of rainfall (average 914). Several climatic factors such as seasonal rainfall amount, intra-seasonal rainfall distribution and dates of onset/cessation of the rains influence crop yields and determine the agricultural calendar $[23,24]$. In particular, the onset of the rainy season appears to be the most crucial information for agricultural management $[25,26]$ since it determines the planting period [27-29]. Traore et al. (2007) [30] emphasized differences between agro-climatic and farmers' definitions of the onset of the rains. The agro-climatic approach defines the onset as the optimal date that ensures sufficient soil moisture during planting and early growing periods to avoid crop failure after sowing [23,29,31,32]. 
Traditionally, sowings begin as early as possible and coincide with the first substantial rainy event [33], which occurs generally around one month before the full establishment of the monsoon [34]. Since the monsoon season has not begun yet, the probability of a post-sowing dry spell is high, increasing the risk of a sowing failure. Farmers balance this risk, inducing a loss of seeds and an increase of labor devoted to re-sowing, with the beneficial nitrogen flush associated with the first rains [35-37]. Moreover, late sowings not only miss this flush but also shorten the growing season and increase weed pressure and weeding [38-40]. In this paper, an attempt is made to illustrate how rainfall determines the choice of sowing date and evaluates the relationship between sowing and onsets dates defined using agro-climatic approaches.

\section{Materials and Methods}

\subsection{Study Area}

Karnataka (located between $11.40^{\circ}-18.27^{\circ} \mathrm{N}$ latitudes and $74.25^{\circ}-78.50^{\circ} \mathrm{E}$ longitudes and covers an area of $19.1 \mathrm{M}$. Ha that accounts for $5.8 \%$ of the total area of the country) has tropical monsoon characterized by hot and moist summers and cool and dry winters [21]. There is a diversity in the climate of the state, influenced by geographical location, oceans, physical features, vegetation and monsoon winds. Hence, the annual temperature and distribution of rain are not the same all over the state. The state has a net cultivated area of 10.5 M Ha, net irrigated area of 3.49 M Ha and net rainfed area of 7.01 M ha [41].

Based on the common rainfall distribution pattern, Karnataka state is classified into four meteorological subdivisions, namely North Interior Karnataka (NIK), South Interior Karnataka (SIK, $13.18^{\circ}-13.32^{\circ} \mathrm{E}$ and $75.82^{\circ}-76.59^{\circ} \mathrm{N}$ ), Coastal subdivision and Malnad subdivision. The study area, i.e., SIK subdivision, comprises 11 districts (Table 1) viz. Bengaluru Urban, Bengaluru rural, Chamarajanagara, Kolar, Mandya, Ramanagara, Chikkaballapura, Chitradurga, Davanagere, Mysore and Tumkur (Figure 1). Within the zone, spatial variability in rainfall was observed (Figure 2) as challenging to make site-specific decisions to educate the farmers about the choice of sowing date in accordance with rainfall.

Table 1. Districts and blocks of SIK from where rainfall data was collected.

\begin{tabular}{|c|c|c|}
\hline Zone & District & Blocks (Location of Rain Gauge) \\
\hline \multirow{4}{*}{ CDZ } & Chitradurga & Chitradurga, Hosadurga, Challakere, Molakalmuru, Holalkere, Hiriyuru \\
\hline & Davanagere & Davanagere, Harihara, Jagaluru \\
\hline & Tumakuru & Madhugiri, Pavaghadha, Sira, Chikkanayakanahalli \\
\hline & Chikkamagaluru & Kaduru \\
\hline \multirow{6}{*}{ EDZ } & Tumakuru & Gubbi, Koratagere \\
\hline & Bangalore (rural) & Devanahali, Doddaballapura, Nelamangala, Hosakote \\
\hline & Ramnagara & Ramnagara, Magadi, Kanakapura, Channapattana \\
\hline & Bangalore (urban) & Bangalore (north), Bangalore (south), Anekal \\
\hline & Kolar & Kolar, Maluru, Bangarapete, Shrinivasapura, Mulabagilu \\
\hline & Chikkaballapur & Chikkaballapur, Shiddalaghatta, Chintamani, Gudibande, Gouribidanuru, Bagepalli \\
\hline \multirow{5}{*}{ SDZ } & Mandya & Mandya, Madduru, Malavalli, S. pattana, Pandavapura, K R Pete, Nagamangala \\
\hline & Mysore & Mysore, K R Nagar, T Narasipura, Nanjanagudu \\
\hline & Chamrajnagar & Chamrajnagar, Yalanduru, Gundlupet, Kollegala \\
\hline & Tumakuru & Tumakuru, Kunigal, Tipaturu \\
\hline & Hassan & Channarayapattana, Arasikere \\
\hline
\end{tabular}




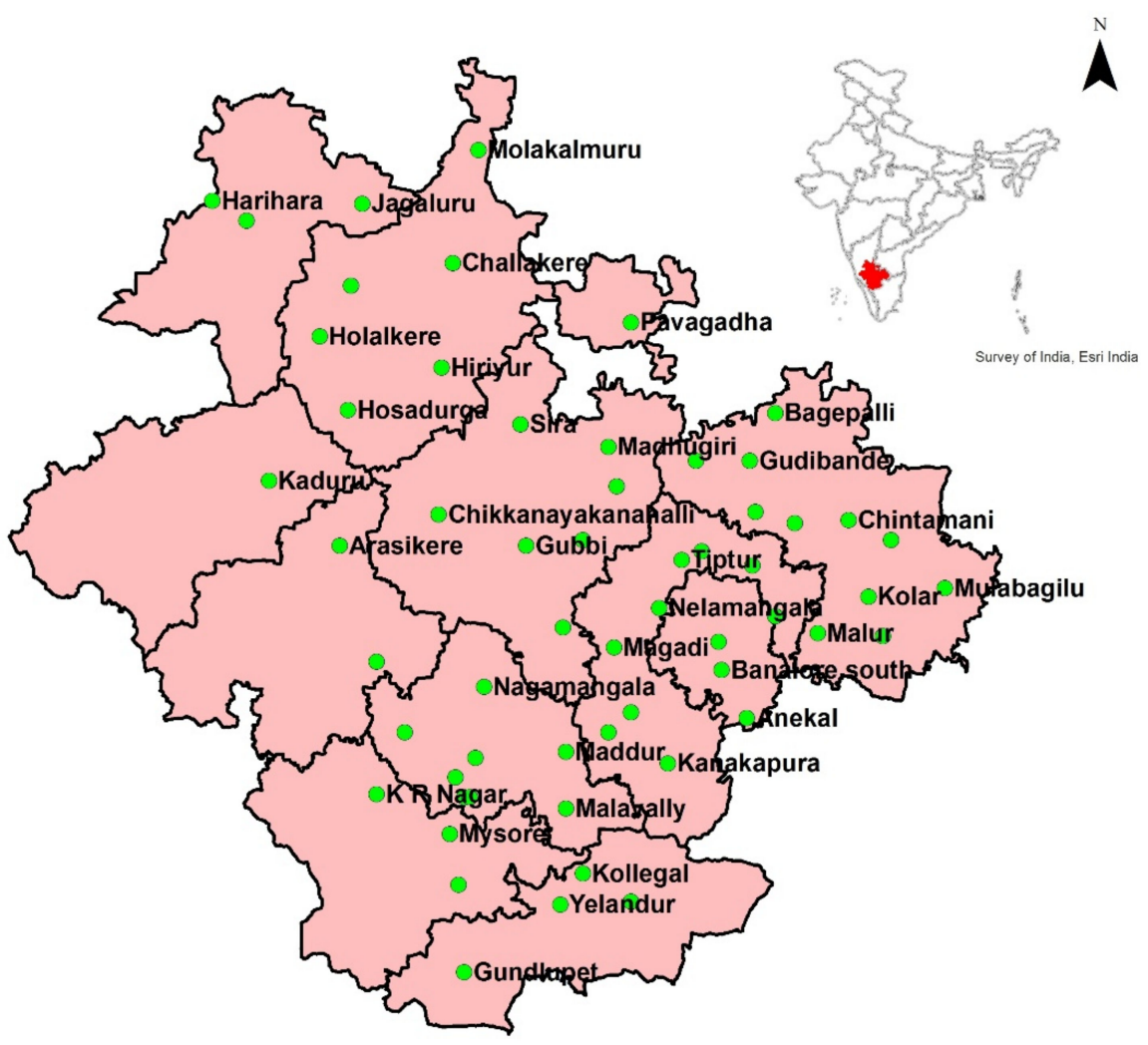

Figure 1. Study area and location of rainfall recording stations.

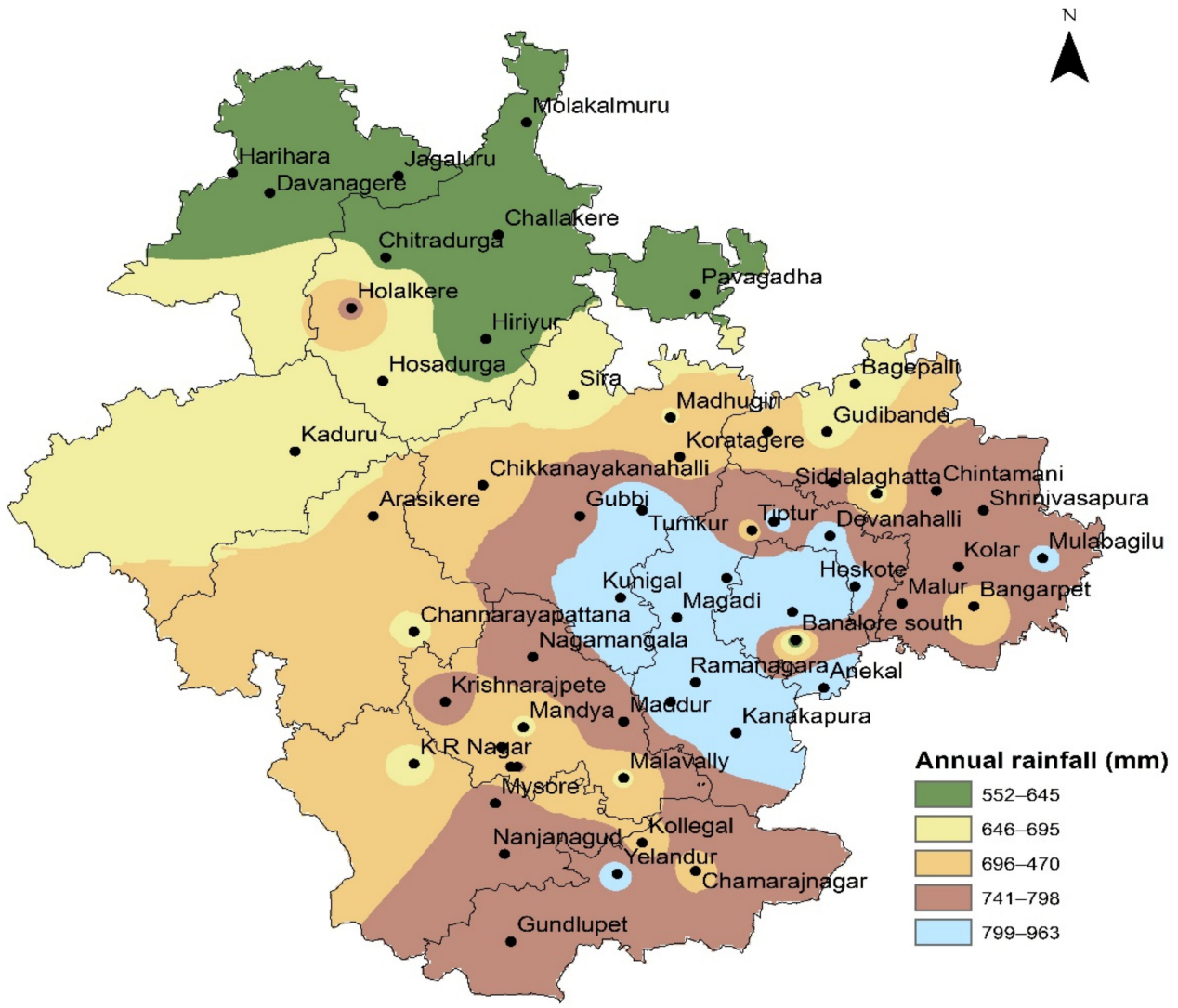

Figure 2. Spatial variability of rainfall over the study area (annual rainfall average of 60 years, 1960-2019). 


\subsection{Meteorological Data}

Long-term (from 1960 to 2019, 60 years) on-site observation data of daily rainfall (mm) for each block headquarters of South Interior Karnataka (SIK) was collected from All India Coordinated Research Project on Agrometeorology (AICRPAM), UAS, GKVK and Karnataka State Natural Disaster Monitoring Center (KSNDMC), Bengaluru (Table 2). The rainfall was measured by rain gauges located at each block headquarters. Daily rainfall of all headquarters was averaged to get average zonal rainfall and summed into month-wise, seasonal and annual data to study trends and shifting patterns in rainfall over the zone. Further, the same data was utilized for the estimation of the onset date.

Table 2. The location of rain gauges and spatial variability of annual rainfall over SIK.

\begin{tabular}{|c|c|c|c|c|c|c|c|}
\hline Station & $\begin{array}{l}\text { Lat. } \\
\left({ }^{\circ} \mathbf{N}\right)\end{array}$ & $\begin{array}{l}\text { Long. } \\
\left({ }^{\circ} \mathrm{E}\right)\end{array}$ & $\mathrm{RF}(\mathrm{mm})$ & Station & $\begin{array}{l}\text { Lat. } \\
\left({ }^{\circ} \mathbf{N}\right)\end{array}$ & $\begin{array}{l}\text { Long. } \\
\left({ }^{\circ} \mathrm{E}\right)\end{array}$ & $\mathrm{RF}(\mathrm{mm})$ \\
\hline \multicolumn{8}{|c|}{ CDZ (average annual rainfall $608.8 \mathrm{~mm}$ ) } \\
\hline Chitradurga & 14.23 & 76.29 & 641.7 & Harihara & 14.53 & 75.8 & 640.4 \\
\hline Hosadurga & 13.79 & 76.28 & 687.7 & Jagaluru & 14.52 & 76.33 & 555.8 \\
\hline Challakere & 14.31 & 76.65 & 620.9 & Madhugiri & 13.66 & 77.2 & 693.3 \\
\hline Molakalmuru & 14.71 & 76.74 & 552.9 & Pavagadha & 14.1 & 77.28 & 596.2 \\
\hline Holalkere & 14.05 & 76.18 & 750.5 & Sira & 13.74 & 76.89 & 666.0 \\
\hline Hiriyur & 13.94 & 76.61 & 590.0 & CK halli & 13.42 & 76.6 & 715.4 \\
\hline Davanagere & 14.46 & 75.92 & 626.3 & Kaduru & 13.42 & 76.6 & 715.4 \\
\hline \multicolumn{8}{|c|}{ EDZ (average annual rainfall $776.7 \mathrm{~mm}$ ) } \\
\hline Gubbi & 13.31 & 76.91 & 792.8 & Anekal & 12.7 & 77.69 & 860.1 \\
\hline Koratagere & 13.31 & 76.91 & 792.8 & Kolar & 13.13 & 78.12 & 774.9 \\
\hline Devanahalli & 13.24 & 77.71 & 815.5 & Malur & 13.13 & 77.94 & 745.5 \\
\hline Doddaballapur & 13.29 & 77.53 & 819.2 & Bangarpet & 12.99 & 78.17 & 695.4 \\
\hline Nelamangala & 12.72 & 77.28 & 874.0 & Shrinivasapura & 13.13 & 77.94 & 745.5 \\
\hline Hoskote & 13.06 & 77.79 & 820.1 & Mulabagilu & 13.16 & 78.39 & 804.3 \\
\hline Ramanagara & 12.72 & 77.28 & 874.0 & Chikkaballapur & 13.43 & 77.72 & 752.9 \\
\hline Magadi & 12.95 & 77.22 & 925.2 & Siddalaghatta & 13.39 & 77.86 & 682.9 \\
\hline Kanakapura & 12.54 & 77.41 & 813.9 & Chintamani & 13.4 & 78.05 & 781.1 \\
\hline Chanapattana & 12.65 & 77.2 & 823.9 & Gudibande & 13.61 & 77.7 & 671.2 \\
\hline Bangalore north & 12.97 & 77.59 & 962.6 & Gouribidanur & 13.61 & 77.51 & 717.3 \\
\hline Bangalore south & 12.92 & 77.59 & 962.6 & Bagepalli & 13.78 & 77.79 & 648.5 \\
\hline \multicolumn{8}{|c|}{ SDZ (average annual rainfall $753.4 \mathrm{~mm}$ ) } \\
\hline Mandya & 12.56 & 76.73 & 683.0 & Nanjanagud & 12.11 & 76.67 & 776.4 \\
\hline Maddur & 12.58 & 77.05 & 770.5 & Chamarajnagar & 11.55 & 76.56 & 787.6 \\
\hline Malavally & 12.38 & 77.05 & 687.7 & Yelandur & 12.04 & 77.03 & 817.9 \\
\hline SR pattana & 12.42 & 76.69 & 683.3 & Gundlupet & 11.80 & 76.69 & 758.1 \\
\hline Pandavapura & 12.49 & 76.66 & 708.1 & Kollegal & 12.15 & 77.11 & 768.1 \\
\hline Krishnarajpete & 12.65 & 76.48 & 768.2 & Tumkur & 13.33 & 77.11 & 864.6 \\
\hline Nagamangala & 12.81 & 76.76 & 785.3 & Kunigal & 13.02 & 77.04 & 816.4 \\
\hline Mysore & 12.29 & 76.64 & 776.2 & Tiptur & 13.26 & 77.46 & 711.2 \\
\hline K R Nagar & 12.43 & 76.38 & 675.9 & CR pattana & 12.9 & 76.38 & 687.5 \\
\hline T Narasipura & 12.42 & 76.71 & 763.0 & Arasikere & 12.9 & 76.38 & 687.5 \\
\hline
\end{tabular}

\subsection{Analysis of Trend in Rainfall}

For trend analysis, a parametric test is more commonly used, which assumes that the data is independent and normally distributed. However, real-world data may rarely satisfy these assumptions. To this end, more powerful nonparametric tests are employed to analyze the trend in the time-series data, especially rainfall data, which does not require the stringent assumption of a parametric test, and can also tolerate the effect of outliers in the data. Mann-Kendall's (M-K) test is one of the most commonly and widely used nonparametric tests for estimating the trend in rainfall data [42]. 


\subsubsection{Mann-Kendall (M-K) Test}

Mann-Kendall trend (M-K) test is a non-parametric test, which is an alternative method to the parametric method of trend analysis. It is the most suitable test for detecting the trend for rainfall data. Since there will be high fluctuation present in the weather parameters, the non-parametric $\mathrm{M}-\mathrm{K}$ test is useful as its statistic is based on the sign of differences, not directly on the values of random variables and therefore trend determined is less affected by the fluctuations and extreme rainfall values.

Test procedure:

Null Hypothesis $(\mathrm{H} 0)=$ There is no presence of a monotonic trend in the rainfall data.

Alternative Hypotheses $(\mathrm{H} 1)=$ There is a presence of a monotonic trend (either decreasing or increasing) in the rainfall data.

The Mann-Kendall statistics ' $S$ ' is given as: $\mathrm{S}=\sum_{\mathrm{k}=1}^{\mathrm{n}-1} \sum_{\mathrm{j}=\mathrm{k}+1}^{\mathrm{n}} \operatorname{sign}\left(\mathrm{x}_{\mathrm{j}}-\mathrm{x}_{\mathrm{k}}\right)$ where $\operatorname{sign}\left(x_{j}-x_{k}\right)=\left\{\begin{array}{c}+1 \text { if }\left(x_{j}-x_{k}\right)>0 \\ 0 \text { if }\left(x_{j}-x_{k}\right)=0 \\ -1 \text { if }\left(x_{j}-x_{k}\right)<0\end{array}\right.$ and $x_{j}$ and $x_{k}$ are the sequential data values and for all $k, j \leq n$ with $k \neq j$, and $n$ is the length of the rainfall data set.

The mean and variance of $S$ are given by: $\mathrm{E}(\mathrm{S})=0$ and $\operatorname{Var}(\mathrm{S})=\frac{1}{18}[n(n-1)(2 n+5)]$ If ties are present in the data, then the variance of $S$ is as follows:

$$
\operatorname{Var}(S)=\frac{1}{18}\left[n(n-1)(2 n+5)-\sum_{i=1}^{n} t_{i}(i)(i-1)(2 i+5)\right]
$$

where $t_{i}$ is the number of ties of extending $i$ [43].

Tau $(\tau)$ measures the strength of the monotonic relationship between $x_{i}$ and $x_{i+1}$. Kendall's tau correlation coefficient is given by:

$$
\tau=\frac{S}{n(n-1) / 2}
$$

If the sample size $n>10$, the standard normal variate $z$ is computed:

$$
z=\left\{\begin{array}{l}
\frac{S-1}{\sqrt{\operatorname{Var}(S)}} \text { if } S>0 \\
0 \quad \text { if } S=0 \\
\frac{S+1}{\sqrt{\operatorname{Var}(S)}} \text { if } S<0
\end{array}\right.
$$

In a two-sided test for trends, $H_{0}$ is accepted if $|z| \leq z_{\alpha} / 2$ at the $\alpha$ level of significance. A positive value of $S$ indicates an 'upward trend;' likewise, a negative value of $S$ indicates 'downward trend' and a zero value of $S$ indicates 'no trend.'

\subsubsection{Modified Mann-Kendall (MMK) Test}

Even though the M-K test is most commonly used test for detecting trends in rainfall data, it assumes that sample data should be serially independent [42]. However, it is well known from many previous studies that most rainfall time-series data exhibit serial correlation. The presence of positive autocorrelation in the data increases the probability of detecting trends even though actual data have no trends and vice versa. To this end, Yue and Wang (2004) [44] developed the Modified Mann-Kendall (MM-K) test, which eliminates the effect of serial correlation present in the time-series data on the M-K test statistic by correcting the variance using Effective Sample Size (ESS). The accuracy of the modified test in terms of its empirical significance level was found to be superior to that of the original Mann-Kendall trend test without any loss of power.

Therefore, the modified variance $V^{*}(S)$ using ESS is given by:

$$
V^{*}(S)=V(S) \cdot \frac{n}{n^{*}}
$$


where $n$ is the Actual Sample Size (ASS) of data, and $n / n^{*}$ is termed as the Correction Factor (C.F), and $n^{*}$ is the ESS, proposed by Yue and Wang [44] and computed by:

$$
n^{*}=\frac{n}{1+2 \rho_{k} \sum_{k=1}^{n-1}\left(1-\frac{k}{n}\right)}
$$

where $\rho_{k}$ is the lag- $k$ serial correlation coefficient, which can be estimated by the sample lag- $k$ serial correlation coefficient $\left(r_{k}\right)$ given by:

$$
r_{k}=\frac{\frac{1}{n-k} \sum_{t=1}^{n-k}\left(x_{t}-\bar{x}_{t}\right)\left(x_{t+k}-\bar{x}_{t}\right)}{\frac{1}{n} \sum_{t=1}^{n}\left(x_{t}-\bar{x}_{t}\right)^{2}} ; \bar{x}_{t}=\frac{1}{n} \sum_{t=1}^{n} x_{t}
$$

Next, the variance of M-K test is replaced by the modified variance, and the M-K test procedure proceeds to identify presence or absence of serial correlation in rainfall data.

\subsubsection{Sen's Slope Estimator}

Sen's slope estimator has been widely used for determining the magnitude of a trend. Sen's slope estimator is a linear slope estimator that works most effectively on monotonic data. Unlike linear regression, it is not greatly affected by data errors, outliers, or missing data. Here, the slope $\left(T_{i}\right)$ of all data pairs can be computed by:

$$
T_{i}=\frac{x_{j}-x_{k}}{j-k} \text { for } i=1,2, \ldots, n
$$

where, $X_{j}$ and $X_{k}$ are considered as data values at time $j$ and $k(j>k)$, correspondingly. The median of these ' $n$ ' values of ' $T i$ ' is represented as Sen's estimator of the slope, which is given as:

$$
Q_{\text {Med }}=\left\{\begin{array}{c}
T_{\frac{N+1}{2}} \text { if } N \text { is odd } \\
\frac{1}{2}\left(T_{\frac{N}{2}}+T_{\frac{N+2}{2}}\right) \text { if } N \text { is even }
\end{array}\right.
$$

In the end, ' $T_{\text {med }}$ ' is computed by a two-sided test at $100(1-\alpha) \%$ confidence interval, and then a true slope can be obtained by this non-parametric test. A positive value of ' $Q_{\text {med }}$ ' indicates an upward or increasing trend, and a negative value of ' $Q_{\text {med }}$ ' gives a downward or decreasing trend in the time-series [45].

\subsubsection{Shifting Pattern in the Rainfall Distribution}

Many time-series are characterized by an abrupt shift in structure, such as sudden jumps in level or volatility. We consider change/shift point to be those time points that divide data set into distinct homogeneous segments. In practice, the number of shifting points will not be known. The ability to detect shifting points is important for both methodological and practical reasons, including the validation of an untested scientific hypothesis, monitoring and assessment of safety-critical processes and the validation of modeling assumptions.

Few non-parametric tests, such as the Standard Normal Homogeneity Test (SNHT), Buishand Range (BR) test and the Pettitt test, can be used to test the null hypothesis, values $Y_{i}$ of the testing variables $Y$ are independent and identically distributed, and the series is considered as homogeneous. Meanwhile, under the alternative hypothesis, SNHT, BR test and Pettitt test assume that the series consists of a break in the mean and considered heterogeneous. These three tests are capable to detect the year where the break occurs. As an alternative to these non-parametric tests, many parametric tests have been proposed by different authors, i.e., Bayesian approaches, Penalizing methods, Likelihood-Ratio estimate, etc. Among those methods, the Likelihood-Ratio method is a popular and most powerful one [42].

The potential for using the likelihood-based approach to detect shifting points was first proposed by [46], who derived the asymptotic distribution of the likelihood ratio test 
statistic for change in the mean within the sequence of normally distributed observations. In the present study, 'changepoint' package of $R$ (ver. 3.6.2) was used to estimate the shifting pattern and point of shift in rainfall distribution.

Likelihood-Ratio Test

Let us consider that each ' $X_{i}$ ' is normally distributed with a mean ' $\mu_{i}$ ' and common variance $\sigma^{2}, \mathrm{i}=1,2, \ldots, \mathrm{n}$. The interest here is about the mean shift. The hypothesis of stability or no shift point (the null hypothesis) is defined as: $H_{0}: \mu_{1}=\mu_{2}=\ldots=\mu_{n}=\mu$ $\mathrm{v} / \mathrm{s} H_{1}: \mu_{1}=\ldots=\mu_{k} \neq \mu_{k+1}=\ldots=\mu_{n}$ where $k$ is the unknown location of the shift point. The testing procedure depends on whether the nuisance parameter $\sigma^{2}$ is known or unknown [47].

When population variance is unknown:

Under $H_{0}$, the likelihood function is

$$
L_{0}\left(\mu, \sigma^{2}\right)=\frac{1}{(\sqrt{2 \pi} \sigma)^{n}} e^{-\sum_{i=1}^{n}\left(x_{i}-\mu\right)^{2}} / 2 \sigma^{2}
$$

and the Maximum Likelihood Estimators (MLEs) of $\mu$ and $\sigma^{2}$ are $\hat{\mu}=\bar{x}=\frac{1}{n} \sum_{i=1}^{n} x_{i}$ and $\hat{\sigma}^{2}=\frac{1}{n} \sum_{i=1}^{n}\left(x_{i}-\bar{x}\right)^{2}$, respectively.

Under $H_{1}$, the likelihood function is

$$
L_{1}\left(\mu_{1}, \mu_{n}, \sigma^{2}\right)=\frac{1}{(\sqrt{2 \pi})^{n}} e^{-\sum_{i=1}^{k}\left(x_{i}-\mu_{1}\right)^{2} / 2 \sigma_{1}^{2}-\sum_{i=k+1}^{n}\left(x_{i}-\mu_{n}\right)^{2} / 2 \sigma_{1}^{2}}
$$

and the MLEs of $\mu_{1}, \mu_{n}$ and $\sigma_{1}^{2}$ are: $\hat{\mu}_{1}=\bar{x}_{k}=\frac{1}{k} \sum_{i=1}^{k} x_{i}, \hat{\mu}_{n}=\bar{x}_{n-k}=\frac{1}{n-k} \sum_{i=k+1}^{n} x_{i}$ and $\hat{\sigma}_{1}^{2}=\frac{1}{n}\left[\sum_{i=1}^{k}\left(x_{i}-\bar{x}_{k}\right)^{2}+\sum_{i=k+1}^{n}\left(x_{i}-\bar{x}_{n-k}\right)^{2}\right]$ respectively. Let, $S=\sum_{i=1}^{n}\left(x_{i}-\bar{x}\right)^{2}$ and $T_{k}^{2}=\frac{k(n-k)}{n}\left(\bar{x}_{k}-\bar{x}_{n-k}\right)^{2}$.

The likelihood procedure-based test statistic is then given by

$$
V=\max _{1 \leq k \leq n-1} \frac{\left|T_{k}\right|}{S}
$$

Under $\mathrm{H}_{0}, \mathrm{~T}_{k} \sim N\left(0, \sigma^{2}\right), S_{k}^{2}=\sum_{i=1}^{k}\left(x_{i}-\bar{x}_{k}\right)^{2}+\sum_{i=k+1}^{n}\left(x_{i}-\bar{x}_{n-k}\right)^{2}$ is distributed as $\sigma^{2} \chi_{n-2}^{2}$, and $T_{k}$ is independent of $S_{k}$; then $T_{k} /\left[S_{k} / \sqrt{n-2}\right] \sim \chi_{n-2}^{2}$. However, simple algebra shows that $V=T_{k} / S \sim t_{n-2}$. Asymptotic distribution of $\mathrm{V}$ is t-distribution with $n-2$ degrees of freedom as $n \rightarrow \infty$ [48].

Then the null hypothesis (that there is no shift point) is rejected in favor of the alternative (there is a single shift point) if $V>c$, where $c$ is some threshold value. This threshold value ' $c$ ' is usually obtained such that $\alpha=\operatorname{Pr}\left(V>c \mid H_{0}\right.$ is true) for some significance level $\alpha$. If the null hypothesis is rejected at some point $k$, then that point $k$ is considered the rainfall pattern shifting point (year) and the mean rainfall for before and after shifting year is calculated.

\subsubsection{The Estimation of the Agro-Climatic Onset of Cropping Season}

Daily rainfall data records from each station falling under the respective block comprised by each zone were collected for analysis, a summary of zones under study, districts, blocks or stations falling under each zone is provided in Table 1 , and meteorological stations used in the study along with their location and yearly rainfall amount is indicated in Table 2. The onset of cropping season is defined using various methods that fall into 
two distinct approaches: the meteorological point of view based on first rains and the agro-climatic one, which considers crop suitability [49].

(A) The Meteorological onsets

The first wet day after April 15th of a 3-day wet spell receiving at least $20 \mathrm{~mm}$. Note that the $20 \mathrm{~mm}$ threshold corresponds roughly to the mean rainfall amount received in a 3-day wet spell (i.e., $>1 \mathrm{~mm}$ ).

(B) The agro-climatic onsets

Based on the Sivakumar agro-climatic onset concept [23] and the work of Marteau et al. (2009) [50], we define the agro-climatic onset date as the first wet day of a 3-day wet spell receiving at least $20 \mathrm{~mm}$ without any 10-day dry spell $(<1 \mathrm{~mm})$ in the following 20 days from 15 April.

The sowing date is defined as the day when the plant-available water in the soil is greater than $10 \mathrm{~mm}$ at the end of the day, followed by a 20-day period during which crop establishment is monitored. The juvenile stage of the crop is considered failed, triggering automatic re-sowing if the simulated daily total biomass decreases during 11 out of 20 days. Sowing date simulations are possible from 15 April to 31 August. Note that the ideal sowing date may not be "ideal" from an agro-ecological, agronomic, socio-economic point of view since it does not take into account nutrient dynamics, pests and diseases, or labor availability.

A user interphase by considering above the pre-requisites for estimating the agroclimatic onset of monsoon was developed using MatLab (Ver. 7.1). The MatLab code interface requires different inputs for simulating the agro-climatic onset. They are explained as follow.

- Start date (calendar date): An estimated date of meteorological onset of rainfall, used to start the simulation of agro-climatic onset.

- Rainfall threshold $(\mathrm{mm})$ : the minimum amount of rainfall required to sow the crop.

- Dry day threshold $(\mathrm{mm})$ : the minimum amount of soil moisture required to meet soil evaporation.

- Dry spell threshold (days): the maximum number of days that crop can sustain even after reaching the dry day threshold. That is, if the crop undergoes moisture stress even up to 10 days, there will not be considerable yield losses.

- Dry spell search period (days): this is decided based on the concept the ability of that particular crop to sustain after germination. If the dry spell occurs before the end of this search period, the model postpones the sowing date to the next moisture abundance period. If not, the first day of the search period will be considered.

After fixing all of the above 'defining inputs,' data is loaded to the model and run to indicate the dry and wet periods in the data matrix window and, finally, the onset date (both date and days after the start of the simulation).

\subsubsection{GIS Mapping}

ArcGIS, a widely used GIS software in research and development purposes, was employed in this study. Geo-referencing of administrative map of dry zones of South Interior Karnataka and digitization of district boundaries were carried out. Then, output data pertaining to agro-climatic onset dates were linked to the polygon map of the study area. Thematic maps pertaining to these parameters were generated using ArcGIS 10.2.2 software.

\section{Results}

\subsection{Trend in Monthly, Seasonal and Annual Rainfall}

For this aspect, non-parametric tests viz. Mann-Kendall (M-K) and Modified MannKendall (MM-K) tests were employed using 'modifiedmk' package of $\mathrm{R}$ (ver. 3.6.2). Before the start of the analysis, the significance of the serial correlation coefficient was tested to check the presence of the serial correlation in all rainfall data series. This test revealed that most of the rainfall data series have a significant serial correlation. Therefore, to eliminate 
the effect of serial correlation on acceptance or rejection of Kendall Tau $(\tau)$, the Modified Mann-Kendall (MM-K) test for variance correction is used.

\subsubsection{Trend in Month-Wise Rainfall}

For month-wise rainfall data of the SIK subdivision, the M-K Tau value, Correction Factor (C.F), Sen's slope estimator (Q) and $p$-values for M-K and MM-K tests are tabulated in Table 3. The M-K test statistic $(\tau)$ values were found to be non-significant at a $5 \%$ level of significance ( $p$-values $\geq 0.05$ ) for all the months, which indicates that there is no monotonic trend in month-wise rainfall data. This may be due to the influence of serial correlation in the month-wise rainfall data. Therefore, to overcome the effect of serial correlation, the MM-K test was employed. MM-K test statistic (Tau) values for April (0.09) were found to be significant ( $5 \%$ level of significance, $p \leq 0.05$ ) but were significant at $1 \%$ level of significance $(p \leq 0.01)$ February (0.08), March (0.15), June (0.17) and August (0.15) months. Conversely, the remaining months, namely January (0.02), May (0.06), July (0.03), September $(-0.07)$, October (0.02), November $(-0.03)$ and December $(-0.04)$, found to be non-significant. Significance and non-significance values of MM-K test statistic (Tau), respectively, indicate the presence and absence of a monotonic trend in the month-wise rainfall data for SIK subdivision. The positive sign of MM-K (Tau) value for February, March, April, June and August months indicated a monotonic increasing trend, and remaining months, viz., January, May, July, September, October, November and December have no monotonic trend in month-wise rainfall data. Sen's slope values towards zero indicate a negligible rate of change in month-wise rainfall of the study area (Figure 3).

Table 3. Analysis of trends in monthly rainfall (1960-2019) in SIK.

\begin{tabular}{|c|c|c|c|c|c|c|c|c|}
\hline \multirow{2}{*}{ Month } & \multicolumn{3}{|c|}{ M-K Test } & \multicolumn{4}{|c|}{ MM-K Test } & \multirow{2}{*}{$\begin{array}{l}\text { Sen's } \\
\text { Slope }\end{array}$} \\
\hline & Tau & $\mathbf{P}$ & Trend $\#$ & Tau & C.F & $\mathbf{P}$ & Trend ${ }^{\#}$ & \\
\hline January & $0.02 \mathrm{NS}$ & 0.15 & - & $0.02 \mathrm{NS}$ & 0.1 & 0.05 & - & 0.00 \\
\hline February & $0.08^{\mathrm{NS}}$ & 0.39 & - & $0.08^{* *}$ & 0.1 & 0.01 & $\uparrow$ & 0.003 \\
\hline March & $0.15^{\mathrm{NS}}$ & 0.08 & - & $0.15^{* *}$ & 0.37 & 0.01 & $\uparrow$ & 0.08 \\
\hline April & $0.09 \mathrm{NS}$ & 0.32 & - & $0.09 *$ & 0.19 & 0.02 & $\uparrow$ & 0.16 \\
\hline May & $0.06^{\mathrm{NS}}$ & 0.47 & - & $0.06^{\mathrm{NS}}$ & 0.4 & 0.31 & - & 0.16 \\
\hline June & $0.17^{\mathrm{NS}}$ & 0.06 & - & $0.17^{* *}$ & 0.2 & $<0.01$ & $\uparrow$ & 0.37 \\
\hline July & $0.03 \mathrm{NS}$ & 0.25 & - & $0.03^{N S}$ & 0.06 & 0.16 & - & 0.05 \\
\hline August & $0.15^{\mathrm{NS}}$ & 0.1 & - & $0.15^{* *}$ & 0.08 & $<0.01$ & $\uparrow$ & 0.56 \\
\hline September & $-0.07^{\mathrm{NS}}$ & 0.44 & - & $-0.07 \mathrm{NS}$ & 0.16 & 0.05 & - & -0.38 \\
\hline October & $0.02 \mathrm{NS}$ & 0.86 & - & $0.02 \mathrm{NS}$ & 0.19 & 0.7 & - & 0.08 \\
\hline November & $-0.03 \mathrm{NS}$ & 0.75 & - & $-0.03^{N S}$ & 0.09 & 0.29 & - & -0.07 \\
\hline December & $-0.04 \mathrm{NS}$ & 0.65 & - & $-0.04^{\mathrm{NS}}$ & 0.31 & 0.41 & - & -0.03 \\
\hline
\end{tabular}

\subsubsection{Trend in Seasonal Rainfall}

For seasonal rainfall data of SIK subdivision, M-K Tau value, Correction Factor (C.F), Sen's slope estimator $(\mathrm{Q})$ and $p$-values for M-K and MM-K tests are tabulated in Table 4. For SIK subdivision, M-K test statistic (Tau) values for all seasons were found to be nonsignificant at a $5 \%$ level of significance ( $p$-values $\geq 0.05$ ) for all the seasons, which indicates that there is no monotonic trend in seasonal rainfall data. This may be due to the influence of serial correlation in the seasonal rainfall data. Therefore, to overcome the effect of serial correlation, if any, the MM-K test was employed. 

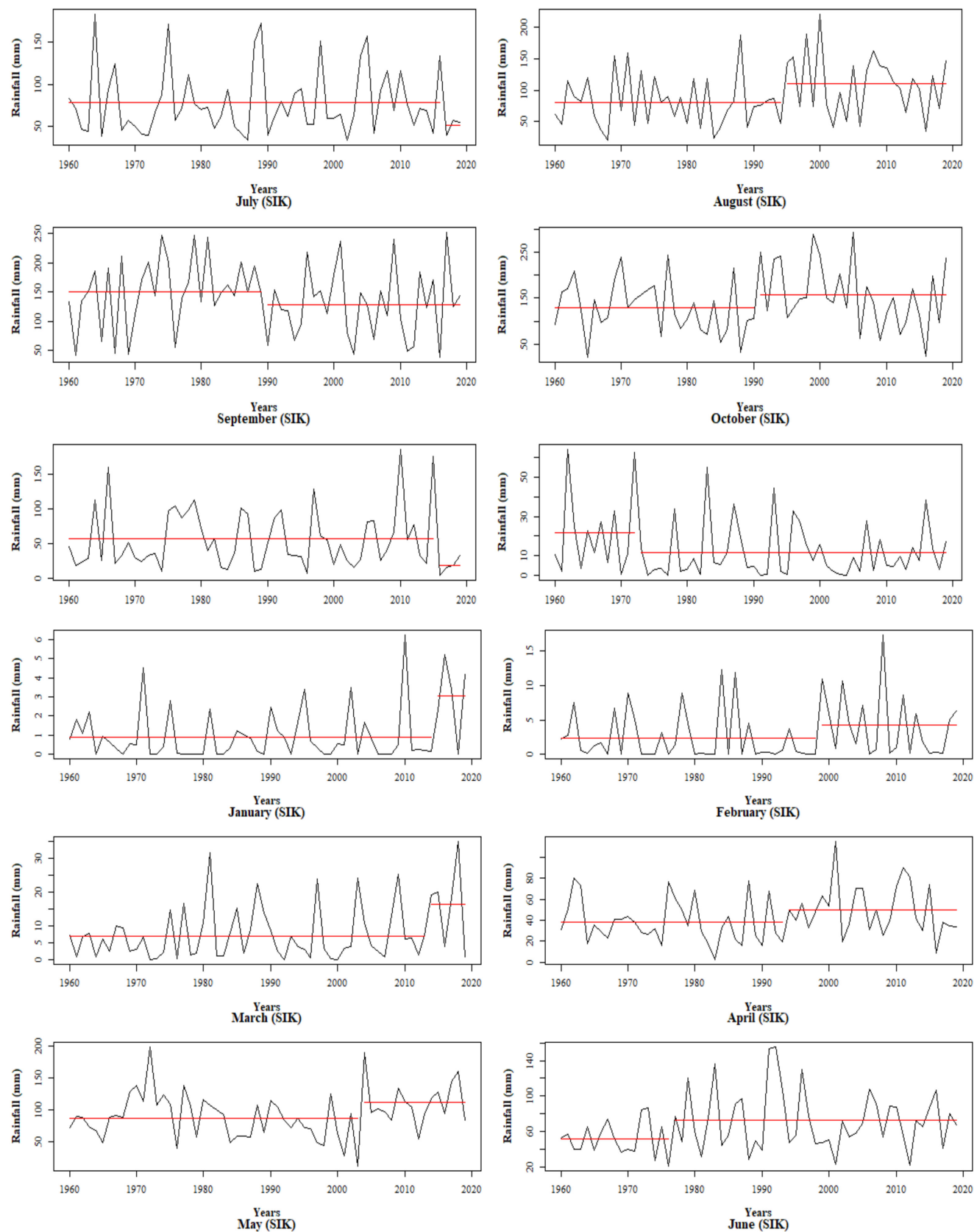

Figure 3. Monthly rainfall distribution along with shifting pattern in SIK over the years (the change in the continuity of horizontal red line indicates the year from which shift in rainfall pattern was observed. The next line starting from above the breakage point indicates a positive shift, i.e., increase in rainfall and vice versa).

MM-K test statistic (Tau) values for winter, pre-monsoon, monsoon and post-monsoon $(0.07,0.15,0.11$ and -0.02$)$ season found to be non-significant $(p \leq 0.05)$. However, employing a modified MM-K test identified a significant $(p \leq 0.01)$ increase in trends of SIK during winter, pre-monsoon and monsoon season $(0.07,0.15$ and 0.11 tau values, respectively), but during post-monsoon, no trend was observed ( $0.57 \mathrm{Tau})$. Significance and non-significance values of the MM-K test statistic (Tau), respectively, indicate the presence and absence of a monotonic trend in the seasonal rainfall data for the SIK subdivision. The positive sign of MMK (Tau) value for the winter season is revealed that there is a monotonic increasing trend and negative sign for monsoon and post-monsoon revealed that there is a monotonic decreasing trend in seasonal rainfall data. In addition, the pre-monsoon season has no monotonic trend. Narayanan et al. (2016) [51] obtain similar results for seasonal and annual 
rainfall data using the MM-K test. Sen's slope values towards zero indicate a negligible rate of change of rainfall for seasonal rainfall of SIK subdivision (Figure 4).

Table 4. M-K and MM-K test statistic (Tau) and Sen's slope estimate for the SIK subdivision for seasonal and annual rainfall $(\mathrm{mm})$ data.

\begin{tabular}{|c|c|c|c|c|c|c|c|c|}
\hline \multirow{2}{*}{ Season } & \multicolumn{3}{|c|}{ M-K Test } & \multicolumn{4}{|c|}{ MM-K Test } & \multirow{2}{*}{$\begin{array}{l}\text { Sen's } \\
\text { Slope }\end{array}$} \\
\hline & Tau & $\mathbf{P}$ & Trend ${ }^{\#}$ & Tau & $\mathrm{CF}$ & $\mathbf{P}$ & Trend ${ }^{\#}$ & \\
\hline Winter & $0.07^{\mathrm{NS}}$ & 0.47 & - & $0.07^{* *}$ & 0.07 & 0.01 & $\uparrow$ & 0.02 \\
\hline Pre-monsoon & $0.15^{\mathrm{NS}}$ & 0.1 & - & $0.15^{* *}$ & 0.32 & $<0.01$ & $\uparrow$ & 0.58 \\
\hline Monsoon & $0.11^{\mathrm{NS}}$ & 0.23 & - & $0.11^{* *}$ & 0.13 & 0.001 & $\uparrow$ & 0.92 \\
\hline Post-monsoon & $-0.02^{\mathrm{NS}}$ & 0.84 & - & -0.02 NS & 0.12 & 0.57 & - & -0.12 \\
\hline Annual & $0.11^{\mathrm{NS}}$ & 0.21 & - & $0.11^{* *}$ & 0.09 & $<0.01$ & $\uparrow$ & 1.47 \\
\hline
\end{tabular}

\# '-' indicates 'No trend', '个' indicates increase in trend. ${ }^{* *}$ significant at $p=0.01$. NS Non significant.
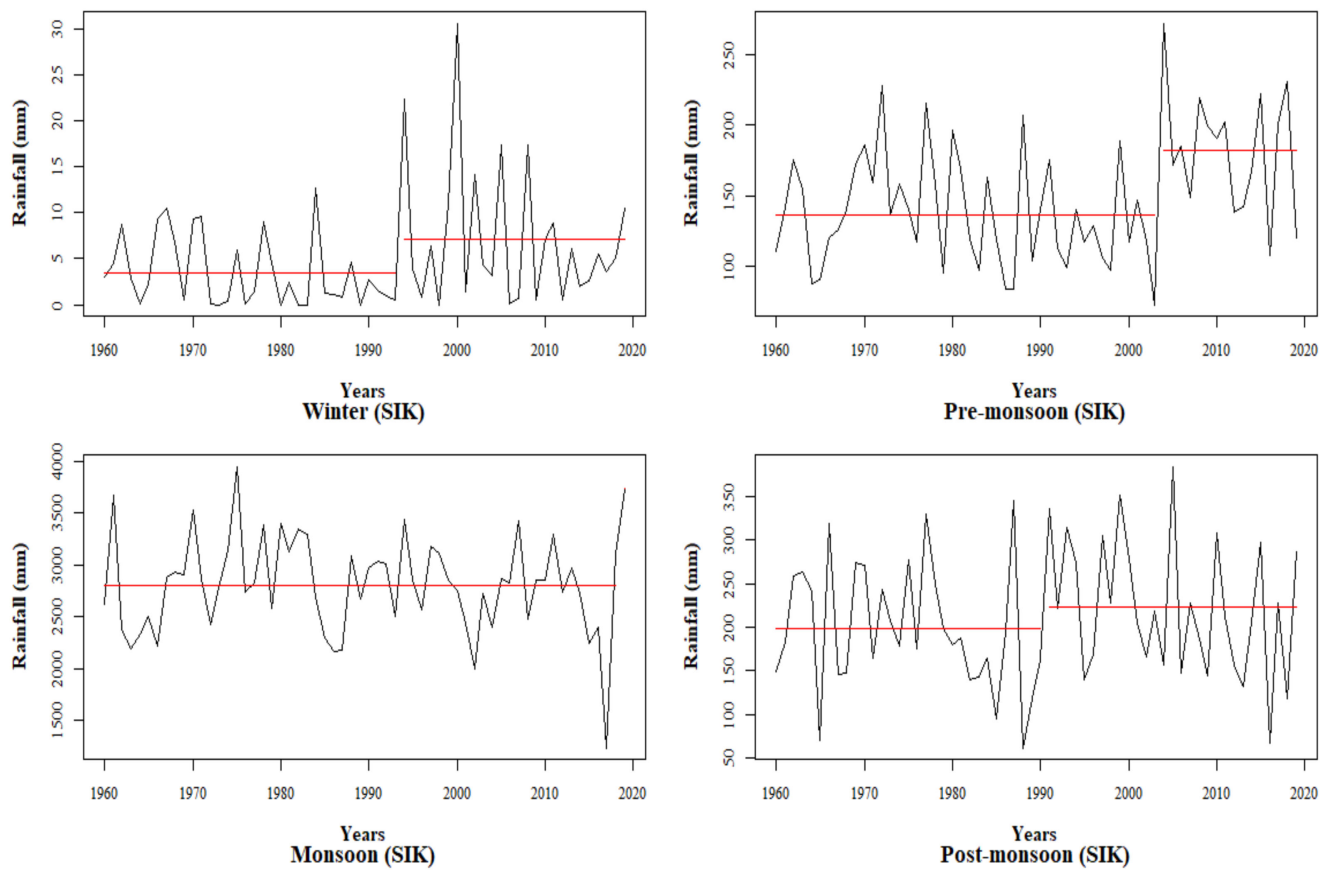

Figure 4. Seasonal rainfall distribution along with shifting pattern in SIK over the years (the change in the continuity of horizontal red line indicates the year from which shift in rainfall pattern was observed. The next line starting from above the breakage point indicates a positive shift, i.e., increase in rainfall and vice versa).

\subsubsection{Trend in Annual Rainfall}

MM-K test statistic (Tau) values for SIK (0.11) subdivisions were found to be significant at a $1 \%$ level of significance $(p \leq 0.01)$. This indicated presence and absence of a monotonic trend in the annual rainfall for the subdivision (Table 4).

\subsection{Shift in Rainfall Distribution Pattern}

To understand the shifting patterns (shifting point or year) in month-wise, seasonal and annual rainfall data of the SIK subdivision of Karnataka, the Likelihood-Ratio was computed by using the 'changepoint' package (in ' $\mathrm{R}$ ') at a $5 \%$ level of significance. Before applying the Likelihood-Ratio test, the distribution of the data was examined using the Shapiro-Wilk test [52]. It was observed that the majority of data sets were following a normal distribution. So, this was taken into account while applying the LikelihoodRatio test. 


\subsubsection{Shifting Pattern in Month-Wise Rainfall Distribution}

For each month-wise rainfall data for the period of 60 years from 1960 to 2019 of the SIK subdivision, the shifting point (year) and the average month-wise rainfall $(\mathrm{mm})$ before and after the shifting point (year) were computed and are illustrated in Table 5 along with the nature of shifting and normal rainfall $(\mathrm{mm})$ of each month. The line graph of monthwise rainfall distribution along with rainfall shifting year and the average month-wise rainfall before and after shifting year are shown in Figure 3.

Table 5. Shifting pattern of monthly rainfall (mm) over SIK.

\begin{tabular}{|c|c|c|c|c|c|c|}
\hline \multirow{2}{*}{ Month } & \multirow{2}{*}{$\begin{array}{c}\text { Shifting } \\
\text { Year }\end{array}$} & \multicolumn{2}{|c|}{ Average RF (mm) } & \multirow{2}{*}{$\begin{array}{l}\text { Change in } \\
\text { RF (mm) }\end{array}$} & \multirow{2}{*}{$\begin{array}{l}\text { Shifting } \\
\text { Nature }\end{array}$} & \multirow{2}{*}{$\begin{array}{l}\text { Normal } \\
\text { RF (mm) }\end{array}$} \\
\hline & & Before & After & & & \\
\hline January & 2014 & 0.9 & 3.0 & 2.2 & $\uparrow$ & 1.8 \\
\hline February & 1998 & 2.3 & 4.2 & 2.0 & $\uparrow$ & 3.5 \\
\hline March & 2013 & 7.1 & 16.3 & 9.2 & $\uparrow$ & 5 \\
\hline April & 1993 & 35.0 & 50.2 & 12.1 & $\uparrow$ & 41 \\
\hline May & 2003 & 56.9 & 112.8 & 25.9 & $\uparrow$ & 96 \\
\hline June & 1976 & 51.5 & 72.5 & 21.1 & $\uparrow$ & 64 \\
\hline July & 2016 & 78.5 & 50.5 & -27.9 & $\downarrow$ & 79 \\
\hline August & 1994 & 80.0 & 109.6 & 29.6 & $\begin{array}{r}\vee \\
\uparrow\end{array}$ & 81 \\
\hline September & 1989 & 151.0 & 128.9 & -22.1 & $\downarrow$ & 135 \\
\hline October & 1990 & 128.5 & 156.5 & 28.0 & $\uparrow$ & 146 \\
\hline November & 2015 & 57.0 & 15.3 & -38.7 & $\downarrow$ & 50 \\
\hline December & 1972 & 21.5 & 11.4 & -10.1 & $\downarrow$ & 14 \\
\hline
\end{tabular}

'\#' indicates 'No trend', ' ' indicates increase in trend, ' $\downarrow$ ' indicates decrease in trend.

The shifting point (year) in month-wise rainfall was found in all the months for the SIK subdivision, i.e., January (2014), February (1998), March (2013), April (1993), May (2003), June (1976), July (2016), August (1994), September (1989), October (1990), November (2015) and December (1972). The average rainfall in the region was increased (Table 5) in the month of January (2.16), February (1.95), March (9.20), April (12.12), May (25.90), June (21.05), August (29.61) and October (27.97), whereas the average rainfall was decreased in the month of July $(-27.93)$, September $(-22.09)$, November $(-38.72)$ and December $(-10.11)$ as compared with before and after the shifting point in rainfall. Further, it can also be observed that the average rainfall in the month of January, February, March, April, May, June, July, August and October were below the normal rainfall before the shifting year, but it was increased after the shifting year, which was above the normal rainfall except for the month of July. Conversely, in the month of September, November, and December, the average rainfall was above normal rainfall before shifting year, but it was decreased after shifting year, which was below the normal rainfall.

\subsubsection{Shifting Pattern in Seasonal Rainfall Distribution}

The shifting point (year) in seasonal rainfall was observed in all seasons viz., winter (1993), pre-monsoon (2003), monsoon (1970) and post-monsoon (1990). Results revealed that the average rainfall was increased for winter (3.69), pre-monsoon (45.71), monsoon (65.13) and post-monsoon (24.90) seasons as compared with before and after shifting point in rainfall (Table 6). Further, the average seasonal rainfall in winter, pre-monsoon, monsoon and post-monsoon was below normal rainfall before shifting year, but it was increased after shifting year, which was above the normal rainfall (Figure 4). 
Table 6. The shifting pattern of seasonal rainfall (mm) data of SIK.

\begin{tabular}{ccccccc}
\hline \multirow{2}{*}{ Season } & $\begin{array}{c}\text { Shifting } \\
\text { Year }\end{array}$ & \multicolumn{2}{c}{ Average RF $(\mathbf{m m})$} & Change in \\
\cline { 3 - 4 } & Before & After & RF (mm) & $\begin{array}{c}\text { Shifting } \\
\text { Nature }\end{array}$ & $\begin{array}{c}\text { Normal } \\
\text { RF (mm) }\end{array}$ \\
\hline Winter & 1993 & 3.5 & 7.1 & 3.7 & $\uparrow$ & 5.0 \\
Pre-monsoon & 2003 & 136.5 & 182.2 & 45.7 & $\uparrow$ & 145.0 \\
Monsoon & 1970 & 322.7 & 387.9 & 65.1 & $\uparrow$ & 359.0 \\
Post-monsoon & 1990 & 198.0 & 222.9 & 24.9 & $\uparrow$ & 210.0 \\
\hline Annual & 1968 & 662.0 & 753.2 & 91.2 & $\uparrow$ & 719.00 \\
\hline '\#' indicates 'No trend', ‘ $\uparrow$ ' indicates increase in trend.
\end{tabular}

\subsubsection{Shifting Pattern in Annual Rainfall Distribution}

As compared with before and after the shifting point in rainfall, the average annual increased for SIK $(91.21 \mathrm{~mm})$. Further, the average annual rainfall in the SIK subdivision was below normal rainfall before the shifting year and increased after the shifting year, which was above the normal rainfall. Inter-annual variability is a better (than mean value) and one of the most important indicators of the reliability of rainfall [53,54].

Thus, understanding the regional level of rainfall trends from past data is of importance for agriculture. In the rainfed condition, success or failure of crops is closely linked with rainfall patterns. Therefore, assessing rainfall variability has been an integral part of water resources planning and management [55]. Since there is a direct relationship between rainfall and agriculture, any small amount of change in the distribution pattern of rainfall would adversely affect the production and productivity of crops [56]. Hence, the study of change in the amount, the pattern of rainfall, and its influence on agriculture have become the most important concern for decision making on crop sowing and further activity.

In the dry lands of SIK, two different sowing strategies are used by the farmers: 'dry seeding' and 'wet seeding.' The first strategy consists of sowing before the rains, i.e., when the soil is still dry [57]. This practice tends to ease germination, reduces the time needed to prepare farmable land before the first rains. However, this strategy is risky since high soil temperatures associated with dry weather as well as scarce and erratic rainfall before the full installation of the monsoon, which is insufficient for full germination of the plant, may spoil the seeds [58]. As the temporal rainfall variability increased, this strategy is less used [59]. Most farmers now wait for a significant rainy event, usually check the rainfall amount by testing the soil moisture to a certain depth, and then sow the same day or the day after. In most parts of the region, the majority of lands are sown in 5 consecutive days after June's first fortnight [60]. However, this practice does not eliminate the risk of sowing failure in case of a dry spell just after the sowing because of false onset of monsoon (a dry spell of $\geq 5$ days in the 12 days following the potential start [61,62]. In order to overcome the lacunae of sowing by these farmers' strategies, novel approaches were developed, one among them is the agro-climatic onset of monsoon proposed by Walter (1967) [31] and further developed by Sivakumar (1988) [23].

The agro-climatic approach defines the onset as the optimal date that ensures sufficient soil moisture during planting and early growing periods to avoid crop failure after sowing $[23,29,31,32]$. The date of onset of rains in this study is defined as that date after 1 May when rainfall accumulated over 3 consecutive days is at least $20 \mathrm{~mm}$ and when no dry spell within the next 30 days exceeds 7 days. This criterion is based on the observations on the establishment of various crops (pigeonpea, finger millet, groundnut, etc.) in the region. Further, the first occurrence of a long dry spell after a specified date could be used as the definition for the end of rain [63]. The date of the end of rain is taken as that date after 1 September, following which no rain occurs over a period of 20 days; this aspect will be worked out in our future studies. The developed MatLab interface requires different inputs for simulating the agro-climatic onset, as explained in Table 7. 
Table 7. Inputs required, fixed values and rationale behind the consideration of values for estimation of Agro-climatic onset.

\begin{tabular}{ccc}
\hline Input. & Value Fixed & Rationale for Consideration \\
\hline Start date & April 1 & To take into account of pre monsoon showers in the region. \\
\hline Rainfall threshold (mm) & $20 \mathrm{~mm}$ & $\begin{array}{r}\text { Sufficient for sowing of major dryland crops such as finger } \\
\text { millet, pigeonpea and other crops [64]. }\end{array}$ \\
\hline Dry day threshold (mm) & $2.5 \mathrm{~mm}$ & $\begin{array}{c}\text { Minimum amount of soil moisture to meet the daily } \\
\text { evaporation need of soil in study area (red sandy loams). }\end{array}$ \\
\hline Dry spell threshold (days) & 10 days & $\begin{array}{r}\text { Maximum number of days that crop can sustain even after } \\
\text { reaching the dry day threshold. }\end{array}$ \\
\hline Dry spell search period (days) & 20 days & $\begin{array}{r}\text { Majority of dryland crops have ability to sustain up to } \\
\text { 20 days with minor amounts of soil moisture. }\end{array}$ \\
\hline
\end{tabular}

\subsubsection{Agro-Climatic Onset of Cropping Season in SIK}

For estimating the onset of the cropping season in the study zone, the SIK is divided into three dry farming regions (Table 1), viz., central dry zone (CDZ), eastern dry zone (EDZ) and southern dry zone (SDZ). Zone wise onset of monsoon are explained as below.

\section{CDZ}

A dry zone receives an average rainfall of $608.8 \mathrm{~mm}$, and most of it is received during April and May as pre-monsoon showers. The simulation was carried out for all the stations coming under each block of four districts of the zone. We got different onset dates for each block since the variability of rainfall amongst them (Table 2). Among all the blocks, an earlier date of 9 May (Table 8) was predicted by the model (38 days after the start of the simulation. That is, 15 April). The average of all the dates simulated for each station indicated that 14 June will be the agro-climatic onset date (30 days after the start of the simulation. That is 15 May).

Table 8. The agro-climatic onset of monsoon over SIK (zones CDZ, EDZ and SDZ, subdivided into blocks) expressed in terms of days after the start date and actual date.

\begin{tabular}{cccccc}
\hline Block & DASD & ACOD & Block & DASD & ACOD \\
\hline \multicolumn{7}{c}{ CDZ } \\
\hline Chitradurga & 38 & 09-May & Harihara & 34 & 04-June \\
Hosadurga & 32 & 17-May & Jagaluru & 32 & 02-June \\
Challakere & 34 & 18-June & Madhugiri & 35 & 05-June \\
Molakalmuru & 30 & 21-May & Pavagadha & 36 & 21-May \\
Holalkere & 37 & 22-May & Sira & 39 & 24-May \\
Hiriyur & 32 & 17-May & Chikkanayakanahhalli & 25 & 10-May \\
Davanagere & 33 & 17-Jun & Kaduru & 25 & 10-May \\
\hline & & \multicolumn{5}{c}{ EDZ } & Anekal & \\
\hline Gubbi & 29 & 14-May & Kolar & 23 & 13-May \\
Koratagere & 29 & 14-May & Malur & 29 & 30-May \\
Devanahalli & 30 & 15-May & Bangarpet & 28 & 13-May \\
Doddaballapur & 28 & 13-May & Shrinivasapura & 28 & 13-May \\
Nelamangala & 30 & 15-May & Mulabagilu & 30 & 15-May \\
Hoskote & 30 & 15-May & Chikkaballapur & 34 & 04-June \\
Ramanagara & 25 & 10-May & Siddalaghatta & 26 & 10-June \\
Magadi & 19 & 20-May & Chintamani & 32 & 16-June \\
Kanakapura & 22 & 23-May & Gudibande & 36 & 06-June \\
Chanapattana & 29 & 30-May & Gouribidanur & 33 & 03-June \\
Bangalore North & 23 & 08-May & Bagepalli & 30 & 14-June \\
Banalore south & 23 & 08-May & \multicolumn{5}{c}{}
\end{tabular}


Table 8. Cont.

\begin{tabular}{cccccc}
\hline Block & DASD & ACOD & Block & DASD & ACOD \\
\hline \multicolumn{7}{c}{ SDZ } & & & \\
Mandya & 22 & 23-May & Nanjanagud & 22 & $23-$ May \\
Maddur & 20 & 05-May & Chamarajnagar & 19 & $20-$ May \\
Malavally & 20 & 05-May & Yelandur & 19 & $20-$ May \\
Shrirangapattana & 19 & 20-May & Gundlupet & 15 & $16-$ May \\
Pandavapura & 20 & 05-May & Kollegal & 26 & $11-$ May \\
Krishnarajpete & 25 & 26-May & Tumkur & 30 & $15-$ May \\
Nagamangala & 17 & 18-May & Kunigal & 19 & $20-$ May \\
Mysore & 22 & 23-May & Tiptur & 21 & 22-May \\
K R Nagar & 22 & 07-May & Channarayapattana & 32 & $17-$ May \\
T Narasipura & 27 & 12-May & Arasikere & 26 & $11-$ May
\end{tabular}

DASD: days after the start of the simulation, ACOD: the agro-climatic onset date.

EDZ

This zone receives an average annual rainfall of $776.7 \mathrm{~mm}$, and $19.2 \%(149 \mathrm{~mm})$ of total rainfall is received during January-May, 52.1\% (404 mm) during June-September and the remaining $28.7 \%$ during October-December $(223 \mathrm{~mm})$. Due to this temporal and spatial variability of rainfall, different onset dates were simulated by the model for different blocks coming under each district of the zone (Table 2). Among all the blocks, an earlier date of 8th May (23 days after the start of the simulation; 15 April as a start date) was predicted by the model for Bangalore north block (Table 8). In this zone, 13 June (28 days after the start of the simulation; 15 May as a start date) is said to be agro-climatic monsoon onset date after taking average of all the dates simulated for each station.

SDZ

An average annual rainfall of $753.4 \mathrm{~mm}$ is received by this zone. Of the $734 \mathrm{~mm}, 27.4 \%$ (201 $\mathrm{mm}$ ) of the total rainfall is received during January-May, 41\% (301 mm) during JuneSeptember and the remaining 31.6\% (232 mm) during October-December. The variability of simulated agro-climatic onset dates was expected due to the spatio-temporal variability of rainfall across each station of the one. The earliest onset date 5th May ( 20 days after the start of the simulation; April 15th as the start date) was simulated at Maddur, Malavally and Pandavapura blocks of Mandya (Table 8). The zonal average of 23 May was determined (22 days after the start of the simulation; 1 May as the start date).

The agro-climatic onset was not the same for each zone due to spatial variability of rainfall along with temporal variability. Each station differed with respect to the onset date (Figure 5), indicating the need to educate farmers at block levels for decision making on sowing the crops. 


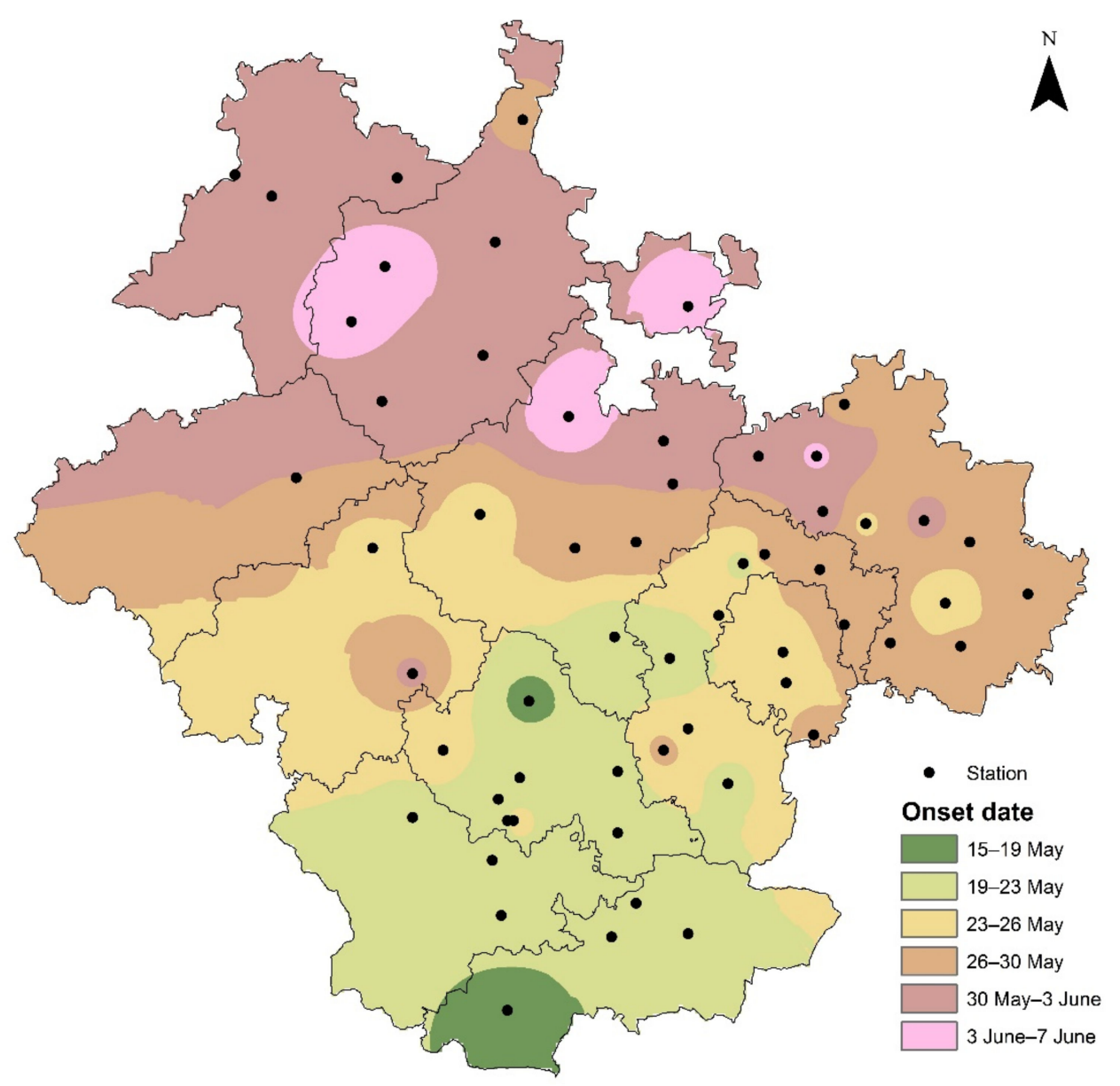

Figure 5. The variability of agro-climatic onset of monsoon over the study area.

\section{Discussion}

Analysis of daily rainfall data from 1960 to 2019 (60 years), an increasing trend of annual rainfall was observed over the SIK between 1960 and 2019, as shown in Figures 3 and 4 . During the study period, there were about 58\% with normal annual rainfall, $21 \%$ with excess rainfall and $21 \%$ with deficit rainfall. Future projections of climate change using Global and Regional Circulation Climate Models with different IPCC emission scenarios indicate an increase of about $5 \%-10 \%$ in summer monsoon rainfall over India [65]. It is also projected that the number of rainy days may decrease by $20 \%-30 \%$, which would mean that the intensity of rainfall is expected to increase. Extreme rainfall may also increase by the end of the year 2100. Another study shows a significant increasing trend in extreme rainfall events over central India during the last 50 years [66].

Several studies over the region reported that the Indian summer monsoon showed remarkable stability in spite of some decadal variations as well as large inter-annual variability. The long-term series of Indian Summer Monsoon Rainfall (ISMR) has no discernible trends, but decadal departures are found above and below the long-time average alternatively for 3 consecutive decades [67]. There is an increase in the occurrence of extreme rainfall events over northwest India in recent decades. An analysis of the longterm trends in individual monthly mean rainfall over India for the period 1870-2003 from linear fits produces negative slopes (average $0.09 \mathrm{~mm} /$ year) for June, July and September and a significant positive slope of similar value for August $[15,68,69]$. This envisages searching for alternative crop production practices.

The trend and shift in rainfall patterns in southern Karnataka imply early onset and cessation of monsoon. Under such conditions, by considering defining inputs such as rainfall threshold, dry day threshold, dry spell threshold etc., the date of onset is estimated 
as 15th May in most parts of the SIK. This emphasizes the advancement of sowing dates in the region for reducing crop losses due to early-season droughts. Early sown crop (May) has the benefit of $657 \mathrm{~mm}$ of mean rainfall with 38 rainy days and can grow up to 125 days [70]. This can be evidenced by higher yields of crops such as groundnut ( $2780 \mathrm{~kg} / \mathrm{ha}$ ) with early sowing (25 May) [71]. The yield of pigeonpea crop sown on the second fortnight of May was significantly higher (1149 kg/ha) as compared to June's first fortnight (901 kg/ha) [72]. Therefore, sowing in this period can be considered as optimum for higher crop productivity. Any normal rainfed crops such as pulses, finger millet, paddy tanked or direct sown paddy and groundnut can be comfortably grown during this period. In the late sowing period, due to delayed rains, medium-duration crops (finger millet, sunflower, pulses) can be sown with the adoption of efficient intercrops. In the very late rainfall situation, only short-duration crops have to be preferred (cowpea, green gram, horse gram, field bean, vegetables) either for subsistence or for fodder purposes [73].

Further, there is a need for subjective tuning (namely amount of rainfall and length of the initial wet spell, length and intensity of post-onset dry spell, etc.) since the onset date is equivocal [41]. In the future, efforts should be made to estimate the cessation dates based on the agro-climatic approach based on other intra-seasonal characteristics of the rainy season, notably the wet or dry spells distribution, especially close to the end of the rainy season. Any medium-term or seasonal prediction of the timing or intensity of the monsoon's withdrawal would thus have a critical impact on crop productivity too because of scarcity or abundance during maturity and harvest period $[70,74]$.

\section{Conclusions}

The first rainy event with at least $20 \mathrm{~mm}$ of rainfall a generally been the stratagem to take up sowing of a monsoon crop in SIK. However, the germinating seedlings have to experience severe to lethal levels of moisture stress if the subsequent rainfall episodes are not sufficiently intense, often referred to as false onset of monsoon, which usually occurs later than the first wet spell [34]. A dry spell of more than seven days during the early stages of the crop growth leads to failure of the crop, necessitating re-sowing. Therefore, it is essential to take into account of rainfall threshold, dry day threshold, dry spell threshold and other edaphic variables in order to arrive at a perfect date of onset of monsoon to decisively plan the most profitable crop sowing schedules that would, in turn, reduce yield losses caused due to early-season drought stress.

Author Contributions: S.H.S., M.M.H. and S.M.S.; resources, conceptualization, validation, K.S.R. and M.T.L.; Analysis, investigation, L.H.; Analysis, investigation, visualization, original draft preparation, S.D.V. and N.L.; data curation, original draft preparation, S.M.S.; review and editing, visualization, supervision. All authors have read and agreed to the published version of the manuscript.

Funding: This research received no external funding.

Data Availability Statement: The data presented in this study are available on request from the corresponding authors.

Acknowledgments: The authors are grateful to meteorological observers for their assistance in data recording.

Conflicts of Interest: The authors declare no conflict of interest.

\section{References}

1. Krishnan, R.; Zhang, C.; Sugi, M. Dynamics of breaks in the Indian summer monsoon. J. Atmos. Sci. 2000, 57, 1354-1372. [CrossRef]

2. Mccarthy, J.; Canziani, O.; Leary, N.; Dokken, D.; White, K. Climate Change 2001: Impacts, Adaptation, and Vulnerability. Contribution of Working Group II to the Fourth Assessment Report of the Intergovernmental Panel on Climate Change; Cambridge University Press: Cambridge, UK, 2001; pp. 19-25.

3. Khanday, M.Y.; Javed, A. Impact of climate change on land use/land cover using remote sensing and GIS in Chopal watershed, Guna, Madhya Pradesh (India). J. Envnt. Res. Dev. 2008, 2, 568-579. 
4. IPCC. Summary for policymakers. In Climate Change 2007: The Physical Sciences Basis; Cambridge University Press: Cambridge, UK, 2007.

5. Subash, N.; Sikka, A.K.; Ram Mohan, H.S. An investigation into observational characteristics of rainfall and temperature in central northeast India: A historical perspective 1889-2008. Theor. Appl. Climatol. 2011, 103, 305-319. [CrossRef]

6. Vijaya Kumar, P.; Bal, S.K.; Subba Rao, A.V.M. All India Coordinated Project on Agrometeorology, Annual Report (2018-19); ICAR Central Research Institute for Dryland Agriculture: Hyderabad, India, 2019; pp. 1-144.

7. Delitala, A.; Cesari, D.; Chesa, P.; Ward, M. Precipitation over Sardinia (Italy) during the 1946-1993 rainy season and associated large scale climate variation. Int. J. Climatol. 2000, 20, 519-541. [CrossRef]

8. Indian Meteorological Department (IMD). 2015. Available online: http:/ / www.imd.gov.in (accessed on 26 November 2020).

9. Prasad, V.S. Onset and withdrawal of Indian summer monsoon. Geophys. Res. Let. 2005, 32, L20715. [CrossRef]

10. Goswami, B.N.; Wu, G.; Yasunari, T. The annual cycle, intra seasonal oscillations, and roadblock to seasonal predictability of the Asian summer monsoon. J. Clim. 2006, 19, 5078-5099. [CrossRef]

11. Taniguchi, K.; Koike, T. Comparison of definitions of Indian summer monsoon onset: Better representation of rapid transitions of atmospheric conditions. Geophys. Res. Let. 2006, 33, L02709. [CrossRef]

12. Fasullo, J.; Webster, P.J. A hydrological definition of Indian Monsoon onset and withdrawal. J. Clim. 2003, 16, 3200-3211. [CrossRef]

13. Rajagopalan, B.; Molnar, P. Combining regional moist static energy and ENSO for forecasting of early and late season Indian monsoon rainfall and its extremes. Geophys. Res. Let. 2014, 41, 4323-4331. [CrossRef]

14. Wang, B.; Ding, Q.; Joseph, P.V. Objective definition of the Indian summer monsoon onset. J. Clim. 2009, 22, 3303-3316. [CrossRef]

15. Stolbova, V.; Surovyatkina, E.; Bookhagen, B.; Kurths, J. Tipping elements of the Indian monsoon: Prediction of onset and withdrawal. Geophys. Res. Let. 2016, 28, 3982-3990. [CrossRef]

16. Flatau, M.K.; Flatau, P.J.; Rudnick, D. The dynamics of double monsoon onsets. J. Clim. 2001, 14, 4130-4146. [CrossRef]

17. Dore, M.H.I. Climate change and changes in global precipitation patterns: What do we know? Environ. Int. 2005, 31, 1167-1181. [CrossRef]

18. Bhowmik, M.; Das, N.; Ahmed, I.; Debnath, J. Rainfall frequency analysis to predict flood in west Tripura district, Tripura, north-east India. Int. J. Geomat. Geosci. 2017, 7, 310-320.

19. Karim, T.H.; Keya, D.R.; Amin, Z.A. Temporal and spatial variations in annual rainfall distribution in Erbil province. Outlook Agric. 2018, 47, 59-67. [CrossRef]

20. Husak, G.J.; Michaelsen, J.; Funk, C. Use of the gamma distribution to represent monthly rainfall in Africa for drought monitoring applications. Int. J. Climatol. 2007, 27, 935-944. [CrossRef]

21. Venkatesh, H.; Shivaramu, H.S.; Rajegowda, M.B.; Rao, V.U.M. Agroclimatic Atlas Karnataka. 2016, p. 211. Available online: https: / / www.uasbangalore.edu.in/index.php/research-en/agrometerology-en (accessed on 21 January 2021).

22. Pulakeshi, H.B.P.; Patil, P.L.; Dasog, G.S.; Radder, B.M.; Bidari, B.I.; Mansur, C.P. Mapping of nutrients status by geographic information system in Mantagani village under northern transition zone of Karnataka. J. Agric. Sci. 2012, 25, 332-335.

23. Sivakumar, M.V. Predicting rainy season potential from the onset of rains in southern Sahelian and Sudanian climatic zones of West Africa. Agric. For. Meteorol. 1988, 42, 295-305. [CrossRef]

24. Maracchi, G.; Bacci, L.; Cantini, C.; Haimanot, M.T. Effect of water deficit in vegetative and post-flowering phases on pearl millet grown in controlled environment. Agric. Med. 1993, 123, 65-71.

25. Ingram, K.T.; Roncoli, M.C.; Kirshen, P.H. Opportunities and constraints for farmers of west Africa to use seasonal precipitation forecasts with burkina- faso as a case study. Agric. Syst. 2002, 22, 331-349. [CrossRef]

26. Barbier, B.; Yacouba, H.; Karambiri, H.; Zorome, M.; Some, B. Human vulnerability to climate variability in the Sahel: Farmers' adaptation strategies in northern Burkina Faso. J. Environ. Manag. 2009, 43, 790-803. [CrossRef] [PubMed]

27. Steward, J.I. Principles and performance of response farming. In Climatic Risk in Crop Production. Models Management for the Semi-Arid Tropics and Sub-Tropics; Ford, W., Muchow, R.C., Bellamy, Z.A., Eds.; CAB International: Wallinford, UK, 1991.

28. Sivakumar, M.V. Empirical analysis of dry spells for agricultural applications in West Africa. J. Clim. 1992, 5, 532-539. [CrossRef]

29. Omotosho, J.B.; Balogun, A.A.; Ogunjobi, K. Predicting monthly and seasonal rainfall, onset and cessation of the rainy season in West Africa using surface data. Int. J. Climtol. 2000, 20, 865-880. [CrossRef]

30. Traore, S.B.; Alhassane, A.; Muller, B.; Kouressy, M.; Somé, L.; Sultan, B.; Oettli, P.; Ambroise, C.; Siéné, L.; Sangaré, S.; et al. Diop, M.; Dingkuhn, M.; Baron, C. Characterizing and modelling the diversity of cropping situations under climatic constraints in West Africa. Atmos. Sci. Lett. 2010, 12, 89-95. [CrossRef]

31. Walter, M.W. Length of rainy season in Nigeria. Niger. Geogr. J. 1967, 10, 123-128.

32. Omotosho, J.B. Onset of thunderstorms and precipitation over northern Nigeria. Int. J. Climtol. 1990, 10, 849-860. [CrossRef]

33. Bacci, L.; Cantini, C.; Pierini, F.; Marachi, G.; Reyniers, F.N. Effects of sowing date and nitrogen fertilization on growth, development and yield of a short day cultivar of millet (Pennisetum glaucum L.). Eur. J. Agron. 1999, 10, 9-21. [CrossRef]

34. Sultan, B.; Janicot, S. The West African monsoon dynamics-The "pre-onset" and "onset" of the summer monsoon. J. Clim. 2003, 16, 3407-3427. [CrossRef]

35. Birch, H.F. The effect of soil drying on humus decomposition and nitrogen availability. Plant Soil. 1958, 10, 1-31. [CrossRef]

36. Sparling, G.P.; Ross, D.J. Microbial contribution to the increased nitrogen mineralization after air-drying of soils. Plant Soil. 1988, 105, 163-167. [CrossRef] 
37. Badiane, A.N. Le Statut Organique d'un Sol Sableux de la Zone Centre-Nord du Sénégal. Ph.D. Dissertation, Institut National Polytechnique de Lorraine, Lorraine, France, 1993.

38. Andrews, D.J. Effects of date of sowing on photosensitive Nigerian sorghums. Exp. Agric. 1973, 9, 337-346. [CrossRef]

39. Stoop, W.A.; Pattanayak, C.M.; Matlon, P.J.; Root, W.R. A Strategy to Raise the Productivity of Subsistence Farming Systems in the West African Semi-Arid Tropics. Proceedings Sorghum in the Eighties; ICRISAT: Patancheru, India, 1981; Volume 2, pp. 519-526.

40. Vaksmann, M.; Traoré, S.B.; Niangado, O. Le photo-périodisme des sorghos africains. Agric. Dév. 1996, 9, $13-18$.

41. Agriculture in Karnataka. Economic Survey Report 2018-2019; Directorate of Economic and Statistics: Karnataka, India, 2019; pp. 2-5.

42. Kodandarama, S.R. Forecasting of Rainfall in Meteorological Subdivisions of Karnataka Using Non-Linear Statistical Models Master's Thesis, University of Agricultural Sciences, Bagalore, India, 2020; pp. 21-50.

43. Sonali, P.; Nagesh Kumar, D. Review of trend detection methods and their application to detect temperature changes in India. J. Hydrol. 2013, 476, 212-222. [CrossRef]

44. Yue, S.; Wang, C. The Mann-Kendall test modified by effective sample size to detect trend in serially correlated hydrological series. Water Res. Manag. 2004, 18, 201-218. [CrossRef]

45. Mondal, A.; Kundu, S.; Mukhopadhyay, A. Rainfall trend analysis by Mann-Kendall test: A case study of north-eastern part of Cuttack district, Orissa. Int. J. Geol. Earth Environ. Sci. 2012, 2, 70-78.

46. Hinkley, D.V. Inference about the change point in a sequence of random variables. Biometrika 1970, 57, 1-17. [CrossRef]

47. Chen, J.; Arjun, K.G. Parametric Statistical Change Point Analysis: With Applications to Genetics, Medicine, and Finance; Springer Science \& Business Media: Berlin/Heidelberg, Germany, 2011.

48. Hawkins, D.M. Testing a sequence of observations for a shift in location. J. Am. Stat. Assoc. 1977, 72, 180-186. [CrossRef]

49. Marteau, R.; Benjamin, S.; Vincent, M.; Agali, A.; Christian, B.; Traore, S.B. The onset of the rainy season and farmers' sowing strategy for pearl millet cultivation in southwest Niger. Agric. For. Meteorol. 2011, 151, 1356-1369. [CrossRef]

50. Marteau, R.; Moron, V.; Philippon, N. Spatial coherence of monsoon onset over western and central Sahel (1950-2000). J. Clim. 2009, 22, 1313-1324. [CrossRef]

51. Narayanan, P. Trend analysis and forecast of pre-monsoon rainfall over India. Weather 2016, 71, 94-99. [CrossRef]

52. Shapiro, S.S.; Wilk, M.B. An analysis of variance test for normality. Biometrika 1965, 52, 591. [CrossRef]

53. Semenov, M.A.; Porter, J.R. Climatic variability and the modelling of crop yields. Agric. For. Meteorol. 1995, 73, 3-4. [CrossRef]

54. Corte-Real, J.; Qian, B.; Xu, H. Regional climate change in Portugal: Precipitation variability associated with large-scale atmospheric circulation. Int. J. Climatol. 1998, 18, 619-635. [CrossRef]

55. Chakraborty, S.; Pandey, R.P.; Chaube, U.C.; Mishra, S.K. Trend and variability analysis of rainfall series at Seonath river basin, Chhattisgarh (India). Int. J. Appl. Sci. Eng. Res. 2013, 2, 425-443.

56. Adarsh, S.; Reddy, J.M. Trend analysis of rainfall in four meteorological subdivisions of southern India using nonparametric methods and discrete wavelet transforms. Int. J. Climatol. 2015, 35, 1107-1124. [CrossRef]

57. Ruth, K.; Darshini, R.; Tashinae, S. Local adaptation strategies in semi-arid regions: Study of two villages in Karnataka, India. Clim. Dev. 2015, 9, 1-15.

58. Ramachandrappa, B.K.; Thimmegowda, M.N.; Krishnamurthy, R.; Srikanth Babu, P.N.; Savitha, M.S.; Srinivasarao, C.H.; Gopinath, K.A.; Ravindra Chary, G. Usefulness and impact of agromet advisory services in eastern dry zone of Karnataka. Indian J. Dryland Agric. Res. Dev. 2018, 33, 32-36. [CrossRef]

59. Amrutha, H.R.; Shreedhar, R. Study of rainfall trends and variability for Belgaum district. Int. J. Res. Eng. Technol. 2014, 3, 148-155.

60. Rajegowda, M.B.; Muralidhara, K.S.; Murali, N.M.; Kumar, T.N.A. Rainfall shift and its influence on crop sowing period. J. Agrometeorol. 2000, 2, 89-91.

61. Davey, E.G.; Mattei, F.; Soloman, S.I. An Evaluation of Climate and Water Resources for the Development of Agriculture in the Sudano-Sahelian Zone of West Africa; WMO Publication: Geneva, Switzerland, 1976; p. 304.

62. Iyengar, R.N. Application of principal component analysis to understand variability of rainfall. Proc. Indian Acad. Sci. 1991, 100, $105-126$.

63. Stern, R.D.; Dennett, M.D.; Garbutt, D.J. The start of the rains in West Africa. J. Climatol. 1981, 1, 59-68. [CrossRef]

64. Morris, R.A.; Zandstra, H.G. Land and climate in relation to cropping patterns in rainfed lowland rice. In Proceedings of the International Rice Research Conference, Los Banos, Philippines, 15 February 1975.

65. Shukla, P.R.; Sharma, K.K.; Amit, G. NATCOM Emission scenarios and Carbon Emissions projections for India. VEA Workshop Scenar. Future Emiss. 2003, 27, 1-16.

66. Goswami, B.N.; Venugopal, V.; Sengupta, D.; Madhusoodanan, M.S.; Xavier, P.K. Increasing trend of extreme rain events over India in a warming environment. Science 2006, 314, 1442-1445. [CrossRef]

67. Subash, N.; Singh, S.S.; Priya, N. Variability of rainfall and effective onset and length of the monsoon season over a sub-humid climatic environment. Atmos. Res. 2001, 99, 479-487. [CrossRef]

68. Rajeevan, M.; Bhate, J.; Jaswal, A.K. Analysis of variability and trends of extreme rainfall events over India using 104 years of gridded daily rainfall data. Geophys. Res. Let. 2008, 35, 1-6.

69. Patra, P.K.; Behera, S.K.; Herman, J.R.; Maksyutov, S.; Akimoto, H.; Yamagata, Y. The Indian summer monsoon rainfall: Interplay of coupled dynamics, radiation and cloud microphysics. Atmos. Chem. Phys. 2005, 5, 2181-2188. [CrossRef] 
70. Ravindrababu, B.T.; Rajegowda, M.B.; Janardhana gowda, N.A.; Girish, J. Weekly, monthly and seasonal rainfall at Bengaluru in Karnataka. J. Agrometeorol. 2010, 12, 263-265.

71. Reddy, V.C.; Babu, B.T.R.; Yogananda, S.B. Growth and flowering behaviour of groundnut varieties in relation to sowing dates during kharif season. Curr. Res. 2000, 29, 163-165.

72. Sharanappa, K.; Shivaramu, H.S.; Thimmegowda, M.N.; Yogananda, S.B.; Prakash, S.S.; Murukannappa. Effect of row spacing, varieties and sowing dates on growth and yield of pigeonpea. Int. J. Curr. Microbiol. Appl. Sci. 2018, 7, 1125-1128.

73. Rao, C.S.; Gopinath, K.A. Resilient rainfed technologies for drought mitigation and sustainable food security. Mausam 2016, 67, 169-182.

74. Sridhara, S.; Gopakkali, P.; Nandini, R. Rainfall probability analysis for crop planning in Shivamogga block of Karnataka. J. Agrometeorol. 2016, 18, 168 . 